\title{
HUBUNGAN STATUS GIZI DENGAN KEJADIAN PIODERMA PADA BALITA DI DESA KUOK
}

\author{
Siska Indriyani ${ }^{1}$, Alini ${ }^{2}$ \\ Sarjana Keperawatan, Universitas Pahlawan Tuanku Tambusai \\ Siskaindrani00@gmail.com¹, alini_09@yahoo.com²
}

\begin{abstract}
Children under the age of five or under five are a group that is prone to nutrition, because they are prone to malnutrition due to lack of food needed. Malnutrition in children will cause decreased immunity, which means that the ability to defend themselves against bacterial infection decreases. Children who have less nutritional status have the potential to suffer from pyoderma. Lack of the amount of food consumed both in quality and quantity can reduce the nutritional status of children. The purpose of this study was to determine the relationship between nutritional status and the incidence of pyoderma in toddlers (1-5 years) in Kuok Village, the working area of Puskesmas Kuok in 2020. This study used an analytical research design with a case control design. The population in this study were all toddlers in Kuok Village as many as 406 people. The samples in this study were 62 children (1-5 years), 31 samples for the case group and 31 samples for the control group. data collection using a questionnaire. Data processing used univariate and bivariate analysis with the ChiSquare test. The results showed that there was a significant relationship between nutritional status and the incidence of pyoderma in toddlers (1-5 years) with $p$ value $=0.001$. In the case group (pyoderma sufferers) most of them had less nutritional status and in the control group most of them had good nutritional status. By holding this research, the researchers expected parents of toddlers to pay more attention to the nutritional status of their children in order to avoid infectious diseases such as pyoderma.
\end{abstract}

\section{Keywords $\quad$ : Nutritional Status, Pioderma}

\begin{abstract}
ABSTRAK
Anak dibawah umur lima tahun atau balita adalah kelompok yang rawan gizi, karena mudah menderita kelainan gizi yang disebabkan kekurangan makanan yang dibutuhkan. Kekurangan gizi pada anak akan menyebabkan penurunan kekebalan tubuh, yang berarti kemampuan untuk mempertahankan diri terhadap serangan infeksi bakteri menjadi menurun. Anak yang memiliki status gizi kurang lebih berpotensi menderita penyakit pioderma. Kurangnya jumlah makanan yang dikonsumsi baik secara kualitas maupun kuantitas dapat menurunkan status gizi pada anak. Tujuan penelitian ini adalah untuk mengetahui hubungan status gizi dengan kejadian pioderma pada Balita (15 tahun) di Desa Kuok wilayah kerja Puskesmas Kuok tahun 2020. Penelitian ini menggunakan desain penelitian analitik dengan rancangan case control. Populasi pada penelitian ini adalah seluruh balita di Desa Kuok sebanyak 406 orang. Sampel pada penelitian ini adalah balita (1-5 tahun) sebanyak 62 orang, 31 sampel untuk kelompok kasus dan 31 sampel untuk kelompok kontrol. pengumpulan data menggunakan kuesioner. Pengolahan data menggunakan analisa univariat dan bivariat dengan uji Chi-Square. Hasil penelitian menunjukkan ada hubungan yang signifikan antara status gizi dengan kejadian pioderma pada balita (1-5 tahun) dengan $p$ value $=0,001$. Pada kelompok kasus (penderita pioderma) sebagian besar memiliki status gizi kurang dan pada kelompok kontrol sebagian besar memiliki status gizi baik. Dengan diadakan penelitian ini peneliti mengharapkan kepada orang tua balita lebih memperhatikan status gizi anaknya agar terhindar dari penyakit infeksi seperti pioderma.
\end{abstract}

Kata Kunci : Pioderma, Status Gizi 


\section{PENDAHULUAN}

Tubuh memiliki berbagai macam sistem pertahanan untuk melindungi diri dari berbagai macam mikroba asing, baik sistem pertahanan internal yang berkaitan dengan imunitas maupaun sistem pertahanan eksternal seperti kulit. Kulit merupakan organ terbesar pada tubuh manusia yang berfungsi sebagai pelindung tubuh dan kulit juga berfungsi sebagai pembungkus otot-otot dan organ-organ dalam serta merupakan jalinan jaringan pembuluh darah, dan semuanya memiliki potensi untuk terserang penyakit yang salah satunya adalah penyakit kulit atau infeksi kulit ( Candra dkk, 2015 ).

Infeksi kulit lebih banyak diderita oleh bayi dan anak dibandingkan dengan orang dewasa. Hal ini dikarenakan kulit bayi dan anak memiliki perbedaan apabila dibandingkan dengan kulit orang dewasa. Kulit bayi dan anak lebih tipis dibandingkan kulit orang dewasa, jaringan antar sel lebih longgar, serta sistem pertahanan tubuh alamiah dan adaftif di kulit belum cukup matang, hal ini dapat menyebabkan kulit dan fungsi proteksinya terhadap infeksi kurang baik atau lemah (Lumataw dkk, 2016). Infeksi kulit yang paling sering ditemukan pada bayi dan anak adalah pioderma. Pioderma merupakan infeksi kulit yang disebabkan oleh bakteri Staphylococcus, dan Streptococcus ( Oentari \& Menaldi, 2015).

Usia balita memang memiliki faktor predisposisi yang memudahkan terkena pioderma, karena pada usia tersebut anak mulai bereksplorasi dengan lingkungan dan memiliki keingintahuan yang tinggi. Proses belajar yang melibatkan alam sekitar seperti bermain dengan tanah dan air yang kotor akan memberikan ruang bagi bakteri patogen untuk masuk. Apalagi anak-anak tersebut belum memahami pentingnya kebersihan diri. Oleh karena itu, perhatian orang tua sangat dibutuhkan untuk mengontrol kebersihan diri anak agar tidak jatuh sakit tanpa mengekang keinginannya untuk belajar (Lumatau dkk, 2016).

Meskipun penyakit pioderma jarang bersifat letal, namun penyakit ini dapat memberikan dampak seperti : stress psikologis yang terjadi pada orang tua dalam menghadapi anak yang demam, susah tidur dan rewel, karena rasa gatal dan nyeri yang dirasakan anak akibat penyakit pioderma. Selain itu efek yang ditimbulkan penyakit ini juga dapat menganggu kegiatan bermain anak (Mistik dkk, 2015).

Menurut Djuanda (2016), faktor pencetus pioderma pada balita antara lain: kurangnya personal hygiene, menurunnya daya tahan tubuh akibat kekurangan gizi, dan anemia. Faktor lain yang dapat menyebabkan pioderma adalah gigitan serangga, sanitasi lingkungan yang buruk, gangguan sistem imun, serta akibat kerusakan jaringan kulit sebelumnya yang menyebabkan fungsi kulit sebagai pelindung akan terganggu, sehingga memudahkan terjadinya infeksi bakteri (Widya, 2016).

Menurut Almatsier (2010, dalam Ariani, 2017) anak dibawah umur lima tahun adalah kelompok yang rawan gizi, karena mudah menderita kelainan gizi yang disebabkan kekurangan makanan yang dibutuhkan. Status gizi merupakan salah satu faktor penting dalam respon imunitas seseorang. Kekurangan gizi pada anak akan menyebabkan penurunan kekebalan tubuh, yang berarti kemampuan untuk mempertahankan diri terhadap serangan infeksi bakteri menjadi menurun, Sehingga menyebabkan anak sangat berpotensial terkena penyakit infeksi (Sanyoto, 2015). Anak yang memiliki status gizi kurang lebih berpotensi menderita penyakit pioderma, kurangnya jumlah makanan yang dikonsumsi baik secara kualitas maupun kuantitas dapat menurunkan status gizi pada anak. Ada beberapa hal yang perlu dihindari bagi anak agar makanannya tidak berkurang, seperti membatasi makanan 
yang kurang menguntungkan, misalnya coklat, permen, dan kue manis, karena hal tersebut dapat membuat anak mudah kenyang sehingga nafsu makannya berkurang (Almatsier, 2010 dalam Ariani, 2017)).

Menurut (WHO) tahun 2010, Prevalensi penyakit pioderma dinegara berkembang yaitu sekitar 1.892 kasus $(62,5 \%)$. Angka kejadian penyakit pioderma di Indonesia pada tahun 2012 sebanyak 1.076 kasus (50,1\%). Pada tahun 2013 dan 2014 terjadi peningkatan penyakit pioderma yaitu sebanyak 1.232 kasus $(58,5 \%)$ menjadi 1.356 kasus (61,3\%) (Depkes RI, 2012).

Data dari Provinsi Riau, penyakit pioderma masih menjadi penyakit yang paling banyak ditemui. Hal ini dapat dilihat dari profil Dinas Kesehatan Provinsi Riau tahun 2012, kota Pekanbaru menderita penyakit pioderma yaitu 4.129 kasus (Dinkes Provinsi Riau, 2012). Berikut ini adalah data penderita pioderma yang ada di 10 Puskesmas di Kabupaten Kampar tahun 2019 :

Tabel 1.1 Data Pioderma Terbanyak di Sepuluh Puskesmas di Kabupaten Kampar tahun 2019

\begin{tabular}{clcc}
\hline No & \multicolumn{1}{c}{ Puskesmas } & Jumlah & Persentase \\
\hline $\mathbf{1}$ & Kuok & $\mathbf{8 6 0}$ & $\mathbf{1 6 , 2 2 \%}$ \\
2 & Kampar & 743 & $14,01 \%$ \\
3 & Bangkinang & 697 & $13,15 \%$ \\
4 & XIII Koto Kampar & 636 & $12,00 \%$ \\
& III & & \\
5 & Siak Hulu I & 557 & $10,60 \%$ \\
6 & Bangkinang & 424 & $8,00 \%$ \\
& Seberang & & \\
7 & Tambang & 405 & $7,64 \%$ \\
8 & Tapung Hulu I & 372 & $7,01 \%$ \\
9 & Siak Hulu III & 323 & $6,09 \%$ \\
10 & Kampar Timur & 283 & $5,33 \%$ \\
\hline & Jumlah & $\mathbf{5 . 3 0 0}$ & $\mathbf{1 0 0 \%}$ \\
\hline
\end{tabular}

(Profil Dinas Kesehatan Kabupaten Kampar, 2019)

Berdasarkan tabel 1 dapat dilihat dari sepuluh Puskesmas yang ada di Kabupaten Kampar pada tahun 2019, Puskesmas Kuok berada pada posisi ke 1 dengan angka kejadian 860 kasus. Puskesmas Kuok terdiri dari 9 Desa yang mana tiap desa terdapat penderita pioderma. Tabel 2 merupakan sebaran penderita pioderma di masingmasing desa.

Tabel 2 Jumlah Kunjungan Penderita Pioderma Bulan januari - Desember di Puskesmas Kuok Tahun 2019

\begin{tabular}{|c|c|c|c|}
\hline No & Desa & Jumlah & Persentase \\
\hline 1 & Desa Kuok & 174 & $20,23 \%$ \\
\hline 2 & $\begin{array}{ll}\text { Desa } & \text { Pulau } \\
\text { Terap } & \end{array}$ & 161 & $18,72 \%$ \\
\hline 3 & Desa Rantau & 154 & $18,00 \%$ \\
\hline 4 & Desa Lereng & 143 & $16,62 \%$ \\
\hline 5 & Desa Silam & 74 & $8,60 \%$ \\
\hline 6 & $\begin{array}{l}\text { Desa Pulau } \\
\text { Jambu }\end{array}$ & 52 & $6,04 \%$ \\
\hline 7 & $\begin{array}{l}\text { Desa Batu } \\
\text { Langkah } \\
\text { Kecil }\end{array}$ & 43 & $5,00 \%$ \\
\hline 8 & $\begin{array}{l}\text { Desa Empat } \\
\text { Balai }\end{array}$ & 36 & $4,19 \%$ \\
\hline 9 & $\begin{array}{l}\text { Desa Bukit } \\
\text { Melintang }\end{array}$ & 23 & $2,67 \%$ \\
\hline & Jumlah & 860 & $100 \%$ \\
\hline
\end{tabular}

(Sumber : Rekam Medik Puskesmas Kuok, 2019)

Berdasarkan tabel 2 diatas terlihat bahwa Desa Kuok merupakan desa dengan jumlah penderita pioderma terbanyak terlihat dari jumlah kunjungannya yaitu 174 orang $(20,23 \%)$.

Penderita pioderma terbanyak pada usia balita (1-5 tahun) yaitu 34 orang $(19,54 \%)$ dari 406 orang jumlah balita yang ada di Desa Kuok. Penelitian yang dilakukan pada tahun 2012 oleh Pangow di Poliklinik Kulit dan Kelamin RSUP Prof. Dr. R. D. Kandou Manado juga menunjukkan bahwa penderita pioderma paling banyak ditemukan pada rentang umur 1-4 tahun, dimana ditemukan 23 kasus $(43,4 \%)$ dari total 53 kasus (Lumatau dkk, 2016).

Berdasarkan survei awal yang dilakukan penulis pada tanggal 20 Maret 2020 pada balita di Desa Kuok, penulis menemukan 10 balita yang menderita penyakit pioderma. Dari 10 balita penderita pioderma, terdapat 6 balita yang gizinya kurang, dan 4 balita lainnya memiliki status gizi baik. Dari wawancara penulis dengan 6 
orang tua balita yang gizinya kurang, tidak mengkonsumsi sayuran dan buah-buahan dan masih banyak yang mengkonsumsi makanan ringan yang tidak sehat. Dari uraian tersebut penulis tertarik untuk mengetahui Hubungan Status Gizi dengan Kejadian Pioderma pada balita (1-5 tahun) di Desa Kuok Wilayah Kerja Puskesmas Kuok tahun 2020.

Adapun tujuan dari penelitian ini adalah untuk mengetahui hubungan status gizi dengan kejadian pioderma pada balita ( 1-5 tahun) di Desa Kuok Wilayah Kerja Puskesmas Kuok tahun 2020.

\section{METODE}

Penelitian ini menggunakan desain penelitian analitik dengan rancangan case control, yaitu penelitian yang dilakukan dengan cara membandingkan antara dua kelompok yaitu kelompok kasus dan kelompok kontrol (Notoatmodjo, 2010). Kelompok kasus yaitu balita yang mengalami pioderma dan kelompok kontrol balita yang tidak mengalami pioderma.

Penelitian ini dilakukan di Desa Kuok Wilayah Kerja Puskesmas Kuok, pada tanggal 15-24 Mei 2020. Populasi pada penelitian ini adalah seluruh balita di Desa Kuok sebanyak 406 orang. Sampel pada penelitian ini adalah orang tua balita yang berumur 1-5 tahun di Desa Kuok dengan kriteria inklusi untuk kelompok kasus yaitu: 1). seluruh balita (1-5 tahun) penderita pioderma yang bertempat tinggal di Desa Kuok, 2).anak berada di rumah. Kriteria inklusi untuk kelompok kontrol adalah: 1).balita (1-5 tahun) yang tidak mengalami pioderma, 2).anak berada di rumah. Sedangkan kriteria eksklusi untuk kelompok kasus yaitu balita (1-5 tahun) penderita pioderma tidak berada di rumah atau pindah rumah. Kriteria eksklusi untuk kelompok control adalah 1).responden yang tidak bersedia menjadi responden, 2).responden yang tidak berada ditempat saat dilakukan penelitian.
Teknik pengambilan sampel yang peneliti gunakan untuk pengambilan sampel kelompok kasus adalah teknik total sampling yaitu seluruh balita yang mengalami pioderma sebanyak 34 orang di Desa Kuok Wilayah Kerja Puskesmas Kuok Tahun 2020. Sedangkan sampel kelompok kontrol diambil dari seluruh balita yang tidak mengalami pioderma di Desa Kuok yang berjumlah 372 balita. Dari 372 balita tersebut diambil 34 balita dengan menggunakan teknik Simple Random Sampling, yaitu pengambilan sampel secara acak sederhana, anggota populasi mempunyai kesempatan yang sama untuk di seleksi sebagai sampel (Notoatmodjo, 2010).

Alat pengumpulan data yang digunakan pada penelitian ini adalah kuesioner dan lembar observasi, lembar pertanyaan kuesioner digunakan untuk memperoleh data yang dibutuhkan. Penilaian status gizi dilakukan dengan cara pengukuran $\mathrm{BB}$ menggunakan timbangan digital serta kuesioner yang terdiri dari pertanyaan usia balita, dan tanggal lahir balita. Kemudian digunakan rumus untuk mengetahui apakah status gizi balita itu baik atau kurang.

Dalam penelitian ini, kriteria penilaian status gizi dikelompokkan menjadi dua macam yaitu: gizi baik jika ZScore > - 2SD, dan gizi kurang jika: ZScore < - 2SD sampai > - 3SD. Data kejadian pioderma didapat dengan menggunakan lembar checklist observasi yaitu peneliti mengamati secara langsung penderita pioderma, apakah penderita sedang mengalami penyakit pioderma atau sudah tidak mengalami penyakit pioderma. Jika penderita sedang mengalami penyakit pioderma maka akan diberi checklist "Ya" jika penderita tidak menderita pioderma maka akan diberi checklist "Tidak".

Analisa yang digunakan adalah analisa univariat dan analisa bivariat. Analisis bivariat menggunakan uji chisquare dengan tingkat kepercayaan 95\% dan tingkat kemaknaan $p$ value $<0,05$. 
Analisa data menggunakan bantuan program komputerisasi.

\section{HASIL}

Penelitian ini dilakukan pada tanggal 15-24 Mei 2020 di Desa Kuok Wilayah Kerja Puskesmas Kuok Tahun 2020. Dari penyebaran kuesioner yang peneliti lakukan, maka didapatkan hasil sebagai berikut :

\section{Analisa Univariat}

\section{Karateristik Responden}

Tabel 3 Karateristik Responden Berdasarkan Jenis Kelamin Dan Umur Balita Di Desa Kuok Wilayah Kerja Puskesmas Kuok Tahun 2020

\begin{tabular}{|c|c|c|c|c|}
\hline \multirow[t]{2}{*}{ Karateristik } & \multicolumn{2}{|c|}{$\begin{array}{c}\text { Kelompok } \\
\text { kasus }\end{array}$} & \multicolumn{2}{|c|}{$\begin{array}{c}\text { Kelompok } \\
\text { kontrol }\end{array}$} \\
\hline & $\mathbf{N}$ & $\%$ & $\mathbf{N}$ & $\%$ \\
\hline \multicolumn{5}{|l|}{ Jenis Kelamin } \\
\hline 1. Laki-Laki & 13 & $41,94 \%$ & 12 & $38,70 \%$ \\
\hline 2. Perempuan & 18 & $58,06 \%$ & 19 & $61,29 \%$ \\
\hline Total & 31 & $100 \%$ & 31 & $100 \%$ \\
\hline \multicolumn{5}{|l|}{ Umur } \\
\hline 1 Tahun & 14 & $45,16 \%$ & 9 & $29,00 \%$ \\
\hline 2 Tahun & 7 & $22,58 \%$ & 8 & $25,81 \%$ \\
\hline 3 Tahun & 3 & $9,67 \%$ & 3 & $9,67 \%$ \\
\hline 4 Tahun & 5 & $13,33 \%$ & 10 & $32,25 \%$ \\
\hline 5 Tahun & 2 & $16,12 \%$ & 1 & $3,33 \%$ \\
\hline Total & 31 & $100 \%$ & 31 & $100 \%$ \\
\hline
\end{tabular}

Dari tabel 3 diketahui bahwa sebagian besar pada kelompok kasus berjenis kelamin perempuan yaitu sebanyak 18 orang $(58,06 \%)$ dan sebagian besar pada kelompok kontrol juga berjenis kelamin perempuan yaitu sebanyak 19 orang $(61,29 \%)$. Pada kelompok kasus sebagian besar berumur 1 tahun yaitu sebanyak 14 orang $(45,16 \%)$ dan sebagian besar pada kelompok kontrol berumur 4 tahun yaitu sebanyak 10 orang $(32,25 \%)$.

\section{Status Gizi}

Tabel 4 Distribusi Frekuensi Responden Berdasarkan Status Gizi Balita (1-5 Tahun) di Desa Kuok Wilayah Kerja Puskesmas Kuok Tahun 2020.

\begin{tabular}{cccccc}
\hline No & $\begin{array}{l}\text { Status } \\
\text { Gizi }\end{array}$ & Kasus & \multicolumn{3}{c}{ Kontrol } \\
\cline { 3 - 6 } & & $\mathbf{N}$ & $\mathbf{\%}$ & $\mathbf{N}$ & $\mathbf{\%}$ \\
\hline 1 & $\begin{array}{l}\text { Gizi } \\
\text { Kurang }\end{array}$ & $\mathbf{1 7}$ & $54,8 \%$ & 4 & $12,9 \%$ \\
2 & $\begin{array}{l}\text { Gizi } \\
\text { Baik }\end{array}$ & 14 & $45,2 \%$ & $\mathbf{2 7}$ & $87,1 \%$ \\
\hline & Total & $\mathbf{3 1}$ & $\mathbf{1 0 0 \%}$ & $\mathbf{3 1}$ & $\mathbf{1 0 0 \%}$ \\
\hline
\end{tabular}

Dari tabel 4 diketahui bahwa sebagian besar balita pada kelompok kasus memiliki status gizi kurang yaitu sebanyak 17 orang $(54,8 \%)$ dan sebagian besar balita pada kelompok kontrol memiliki status gizi baik yaitu sebanyak 27 orang $(87,1 \%)$.

\section{Analisa Bivariat}

Analisis bivariat digunakan untuk mengetahui hubungan antara variabel bebas dengan variabel terikat yaitu hubungan status gizi dengan kejadian pioderma di Desa Kuok Wilayah Kerja Puskesmas Kuok Tahun 2020.

\section{Tabel 5 Hubungan Status Gizi Dengan Kejadian Pioderma Pada Balita (1-5 Tahun) di Desa Kuok Wilayah Kerja Puskesmas Kuok Tahun 2020.}

\begin{tabular}{|c|c|c|c|c|c|c|c|c|c|}
\hline \multirow[t]{4}{*}{$\mathrm{N}_{0}$} & \multirow[t]{4}{*}{ Status Gizi } & \multicolumn{2}{|c|}{ Kasus } & \multicolumn{2}{|c|}{ Kontrol } & & & \multirow[t]{4}{*}{ OR } & $P$ \\
\hline & & \multirow{2}{*}{\multicolumn{2}{|c|}{$\begin{array}{l}\text { Penderita } \\
\text { Pioderma }\end{array}$}} & \multirow{2}{*}{\multicolumn{2}{|c|}{$\begin{array}{c}\text { Bukan } \\
\text { Penderita } \\
\text { Pioderma }\end{array}$}} & \multirow{2}{*}{\multicolumn{2}{|c|}{ Total }} & & \\
\hline & & & & & & & & & \\
\hline & & $\mathrm{N}$ & $\%$ & $\mathrm{~N}$ & $\%$ & $\mathrm{~N}$ & $\%$ & & \\
\hline 1 & Gizi Kurang & 17 & $54,8 \%$ & 4 & $12,9 \%$ & 21 & $33,9 \%$ & 8,196 & 0,001 \\
\hline 2 & Gizi Baik & 14 & $45,2 \%$ & 27 & $87,1 \%$ & 41 & $66,1 \%$ & & \\
\hline & Total & 31 & $100 \%$ & 31 & $100 \%$ & 62 & $100 \%$ & & \\
\hline
\end{tabular}

Berdasarkan tabel 5 diketahui bahwa dari 31 responden penderita pioderma (Kasus) terdapat 14 orang $(45,2 \%)$ yang memiliki status gizi baik, sedangkan dari 31 responden yang bukan penderita pioderma (Kontrol) terdapat 4 orang $(12,9 \%)$ yang memiliki status gizi kurang. Berdasarkan uji statistik dengan chi-square, maka diperoleh nilai $p$ value $=0,001$ yang berarti terdapat hubungan yang signifikan antara status gizi dengan kejadian pioderma pada balita di Desa Kuok Wilayah Kerja Puskesmas Kuok Tahun 2020. Berdasarkan nilai OR (Odds Ratio) 8,196 yang artinya responden yang memiliki status gizi kurang akan berpeluang 
8,196 kali berisiko mengalami penyakit pioderma dibandingkan orang yang memiliki status gizi baik.

\section{PEMBAHASAN}

Hasil analisa bivariat dari variabel hubungan status gizi dengan kejadian pioderma pada balita (1-5 tahun) di Desa Kuok Wilayah Kerja Puskesmas Kuok Tahun 2020 diperoleh nilai $P$ Value $=0,001$ $<$ 0,05 dimana, dari 31 responden yang menderita pioderma terdapat 17 orang $(54,8 \%)$ yang memiliki status gizi kurang. Menurut asumsi peneliti anak yang menderita pioderma yang memiliki status gizi kurang disebabkan karena sering mengkonsumsi makanan ringan yang tidak sehat dan jarang mengkonsumsi makanan yang bergizi salah satunya sayur dan susu, sehingga asupan makanan tidak terpenuhi dengan baik, dan mengakibatkan berat badan anak menjadi menurun. Hal ini sangat perlu diperhatikan oleh orang tua agar memberikan anaknya makanan yang bergizi dan membatasi mengkonsumsi makanan ringan yang tidak sehat.

Menurut teori dari Sanyoto (2015) apabila seseorang memiliki status gizi kurang maka kekebalan tubuhnya akan melemah, dan kemampuan untuk mempertahankan dirinya terhadap serangan bakteri yang masuk menjadi menurun, sehingga menyebabkan anak mudah terinfeksi oleh penyakit.

Penelitian ini sesuai dengan penelitian yang dilakukan oleh Putra mengenai Hubungan Tingkat Status Gizi Dengan Kejadian Pioderma Pada Anak Usia 6-10 Tahun Di SDN Petoran Surakarta Tahun 2018. Hasil menunjukkan ada hubungan antara tingkat status gizi dengan kejadian pioderma.

Menurut teori dari Djuanda (2016) faktor yang dapat menyebabkan pioderma yaitu kurangnya personal hygiene dan anemia. faktor lain yang dapat menyebabkan pioderma adalah gigitan serangga, sanitasi lingkungan yang buruk, gangguan sistem imun, serta akibat kerusakan jaringan kulit sebelumnya yang menyebabkan fungsi kulit sebagai pelindung akan terganggu, sehingga memudahkan terjadinya infeksi bakteri (Widya, 2016). Hal ini membuktikan bahwa dari hasil penelitian yang dilakukan, 14 orang $(45,2 \%)$ penderita pioderma yang memiliki status gizi baik, 8 diantaranya memiliki personal hygiene yang buruk seperti bermain di tempat yang kotor tanpa menggunakan alas kaki dan kuku tangan dan kaki terlihat kotor, 6 diantaranya memiliki sanitasi lingkungan rumah yang tidak sehat seperti banyaknya sampah berserakan dan tidak adanya tempat pembuangan air limbah khusus, sehingga air limbah tergenang di perkarangan rumah. Hal ini berarti jika balita tidak bermain di tempat yang kotor dan menggunakan alas kaki saat bermain maka kemungkinan balita tidak mengalami pioderma.

Sedangkan dari 31 responden yang tidak menderita pioderma terdapat 4 orang $(12,9 \%)$ yang memiliki status gizi kurang. Hal ini disebabkan karena asupan nutrisi yang tidak terpenuhi dengan baik. Menurut Almatsier (2010, dalam Ariani, 2017) balita atau anak dibawah umur lima tahun adalah kelompok yang rawan gizi, karena mudah menderita kelainan gizi yang disebabkan kekurangan makanan yang dibutuhkan. Masalah gizi kurang biasanya disebabkan oleh kemiskinan, kurangnya persediaan pangan, dan kurangnya pengetahuan masyarakat tentang gizi dan kesehatan. Ada beberapa hal yang perlu dihindari bagi anak agar makanannya tidak berkurang, seperti membatasi makanan yang kurang menguntungkan, misalnya coklat, permen, dan kue manis, karena hal tersebut dapat membuat anak mudah kenyang sehingga nafsu makannya berkurang (Almatsier, 2010 dalam Ariani, 2017).

\section{KESIMPULAN}

Berdasarkan hasil penelitian, maka dapat disimpulkan ada hubungan antara 
status gizi dengan kejadian pioderma pada balita (1-5 tahun) di Desa Kuok Wilayah Kerja Puskesmas Kuok Tahun 2020.

\section{DAFTAR PUSTAKA}

Almatsier. (2010). Status Gizi Lebih. Dalam Ariani, P.A. (2017). Ilmu Gizi. Jakarta : Nuha Medika.

Almatsier. (2010). Status Gizi Baik. Dalam Ariani, P.A. (2017). Ilmu Gizi. Jakarta: Nuha Medika.

Almatsier. (2010). Status Gizi Kurang. Dalam Ariani, P.A. (2017). Ilmu Gizi. Jakarta : Nuha Medika.

Almatsier. (2010). Status Gizi Buruk. Dalam Ariani, P.A. (2017). Ilmu Gizi. Jakarta : Nuha Medika.

Djuanda, A. (2016). Klasifikasi Pioderma. Dalam Srilinuwih (Ed). Ilmu Penyakit Kulit Dan Kelamin Edisi Ketujuh. Jakarta : Fakultas Ilmu Kedokteran Universitas Indonesia.

Djuanda, A. (2016). Bentuk-Bentuk Pioderma. Dalam Srilinuwih (Ed). Ilmu Penyakit Kulit Dan Kelamin Edisi Ketujuh. Jakarta : Fakultas Ilmu Kedokteran Universitas Indonesia.

Depkes, RI (2012). Profil Kesahatan Indonesia di akses tanggal 18 Maret 2020.

Dinkes Kabupaten Kampar (2019) diakses tanggal 18 Maret 2020.

Dinkes Provinsi Riau (2012). Jurnal eClinic, Volume 4, Nomor 2, JuliDesember 2016 di akses tanggal 18 Maret 2020.

Lumataw, dkk. (2016). Profil Pioderma Pada Anak Di Poliklinik Kulit Dan
Kelamin RSUP Prof. Dr. R. D. Kandou Manado. Di akses tanggal 15 Maret 2020.

Mistik, dkk. (2015). Profil Pioderma Pada Anak Usia 0-14 Tahun Di Rumah Sakit Umum Pusat Sanglah Denpasar Periode Juni 2015-Juni 2016. Di akses tanggal 15 Maret 2020.

Notoatmodjo, S. (2010). Metodologi Penelitian Kesehatan. Jakarta : Rineka Cipta.

Nugraha, P.H. (2018). Hubungan Tingkat Status Gizi Dengan Kejadian Pioderma Superfisialis Pada Anak Usia 6-10 Tahun. Di akses tanggal 15 Maret 2020.

Oentari \& Menaldi. (2015). Kapita Selekta Kedokteran. Jakarta : Media Aesculaplus.

Widya, J. (2016). Pioderma Pada Bayi Dan Anak. Di akses tanggal 17 Maret 2020. 